\title{
PENGARUH DISIPLIN KERJA GURU TERHADAP DISIPLIN BELAJAR SISWA SEKOLAH DASAR
}

\author{
Iswan $^{1}$, dan Indah Hadidah ${ }^{2}$ \\ ${ }^{1,2}$ Universitas Muhammadiyah Jakarta \\ Email: iswanfipumj@gmail.com
}

\section{Info Artikel}

Sejarah Artikel:

Diserahkan 12 November 2019

Direvisi 18 November 2019

Disetujui 18 November 2019

Keywords:

discipline of teachers, and

student learning discipline

\begin{abstract}
The purpose of this study are 1) knowing the application of the work discipline of teachers in SDN 02 Sawangan Depok, 2) knowing the application of student learning discipline in SDN 02 Sawangan Depok, and 3) knowing the effect of the teacher's work discipline on the learning discipline of fourth grade students in the SDN 02 Sawangan Depok.

This Research uses a quantitative approach. Data was collected by distributing questionnaires to 30 students as respondents. Test the validity and reliability of the questionnaire in this study using the Statistical Package for the Social Sciences (SPSS) program with type 21.00 .

The results showed that 1) based on the results of the rating scale analysis test obtained a questionnaire value of 1150 with intervals ranging from 1081-1440. This means that the application of the work discipline of teachers in SDN 02 Sawangan Depok in the category of "Very Good". 2) the application of student learning discipline in class IV at SDN 02 Sawangan Depok based on the results of the scalae rating analysis test obtained a questionnaire value of 1494 the interval ranged from 1441-1920, so it can be concluded student discipline in the SDN 02 Sawangan Depok in the category of "Very Good". 3) there is a significant influence between the teacher's work discipline on student learning discipline at SDN 02 Sawangan Depok which is supported by a correlation number of $0.409>$ rtable 0.374 at a significance level of $5 \%$ and also the results of the F test which show an Fcount of 5.617> Ftable of 4.20. Because the value of the correlation test shows rcount> of rtable and the results of a simple regression test show that Fcount> Ftable it can be stated that the hypothesis there is an influence between the teacher's work discipline variables on student learning discipline is accepted. While seen from the coefficient of determination $(R)$ of $16.7 \%$ it is known that the influence between the teacher's work discipline variables on student learning discipline is $16.7 \%$ which is quite influential.
\end{abstract}

\begin{abstract}
Abstrak
Tujuan penelitian ini yaitu 1) mengetahui penerapan disiplin kerja guru di SDN 02 Sawangan Depok, 2) mengetahui penerapan disiplin belajar siswa di SDN 02 Sawangan Depok, dan 3) mengetahui pengaruh disiplin kerja guru terhadap disiplin belajar siswa kelas IV di SDN 02 Sawangan Depok.

Penelitian menggunakan pendekatan kuantitatif. Data dikumpulkan dengan cara penyebaran angket kepada 30 orang siswa sebagai responden. Uji validitas dan reliabilitas angket pada penelitian ini menggunakan program Statistical Package for the Social Sciences (SPSS) dengan tipe 21.00 .

Hasil penelitian menunjukkan bahwa 1) berdasarkan hasil uji analisa rating scale diperoleh nilai angket sebesar 1150 dengan interval berkisar antara 1081-1440. Hal ini berarti bahwa penerapan disiplin kerja guru di SDN 02 Sawangan Depok dalam kategori "Sangat Baik". 2) penerapan disiplin belajar siswa kelas IV di SDN 02 Sawangan Depok berdasarkan hasil uji analisa rating scalae diperoleh nilai angket sebesar 1494 dengan interval berkisar antara 1441-1920, sehingga dapat disimpulkan disiplin belajar siswa di SDN 02 Sawangan Depok kategori "Sangat Baik". 3) terdapat pengaruh yang cukup signifikan antara disiplin kerja guru terhadap disiplin belajar siswa di SDN 02 Sawangan Depok yang didukung angka korelasi sebesar $0.409>\mathrm{r}_{\text {tabel }} 0.374$ pada taraf signifikansi 5\% dan juga hasil uji $\mathrm{F}$ yang menunjukkan $F_{\text {hitung }}$ sebesar $5.617>F_{\text {tabel }}$ sebesar 4.20. Karena nilai uji korelasi menunjukkan $\mathrm{r}_{\text {hitung }}>$ dari $\mathrm{r}_{\text {tabel }}$ dan hasil uji regresi sederhana menunjukkan bahwa $\mathrm{F}_{\text {hitung }}>$ $F_{\text {tabel }}$ maka dapat dinyatakan bahwa hipotesis terdapat pengaruh antara variabel disiplin kerja guru terhadap disiplin belajar siswa diterima. Sedangkan dilihat dari koefisien determinasi $(\mathrm{R})$ sebesar 16.7\% diketahui bahwa pengaruh antar variabel disiplin kerja guru terhadap disiplin belajar siswa ialah sebesar $16.7 \%$ yakni cukup berpengaruh.
\end{abstract}

(C) 2019 Universitas Muria Kudus 


\section{PENDAHULUAN}

Disiplin adalah suatu keadaan tertib, ketika orang-orang yang tergabung dalam suatu sistem tunduk pada peraturan-peraturan yang ada dengan senang hati (Mulyasa, 2009). Berdasarkan definisi tersebut disiplin merupakan keadaan guru, kepala sekolah, dan staf serta peserta didik yang tergabung dalam sekolah, tunduk kepada peraturan yang telah ditetapkan dengan senang hati.

Disiplin sekolah bertujuan untuk membantu peserta didik menemukan dirinya, mengatasi, dan mencegah timbulnya masalahmasalah disiplin, serta berusaha menciptakan situasi yang menyenangkan dalam pembelajaran sehingga mereka menaati segala peraturan yang telah ditetapkan. Akan tetapi akhir-akhir ini masalah disiplin sering disepelekan, bahkan banyak sekali pelanggaran-pelanggaran yang dilakukan oleh masyarakat terhadap peraturan yang telah disepakati dan ditetapkan. Demikian halnya di sekolah, lembaga pendidikan yang seharusnya menjadi miniatur masyarakat dalam membina disiplin ternyata tidak dapat diandalkan.

Tidak sedikit pelanggaran yang dilakukan oleh kepala sekolah, guru, maupun peserta didik, mulai dari penyalahgunaan dana bantuan operasional oleh kepala sekolah, hingga pembocoran soal atau kunci jawaban oleh guru. Semua itu disebabkan antara lain karena kurangnya atau lemahnya disiplin. Banyaknya perilaku negatif dan penyimpangan di sekolah yang dilakukan peserta didik dapat menganggu efektivitas pembelajaran. Hal ini sangat erat kaitannya dengan kedisiplinan yang ditetapkan sekolah, baik untuk guru maupun untuk siswa. Oleh karena itu, dalam upaya untuk meningkatkan kualitas pembelajaran antara lain dapat dilakukan dengan pembinaan disiplin sekolah.

Dalam membentuk perilaku disiplin ini, guru bertanggungjawab mengarahkan pada yang baik, harus menjadi contoh, sabar, dan penuh pengertian. Di sekolah, guru dapat menanamkan rasa kedisiplinan baik dalam dirinya sendiri ataupun kepada siswanya sehingga dapat menjalankan tugas dan tanggungjawabnya dengan baik.

Tanpa adanya sikap disiplin yang dimiliki oleh seorang guru dalam menjalankan tugasnya, maka tidak heran bila hasil akhir pembelajaran tidak sesuai dengan yang dicita-citakan. Rendahnya disiplin kerja guru dapat mengakibatkan buruknya mutu pendidikan di sekolah.

Kedisiplinan harus ditanamkan kepada setiap individu, baik itu para guru ataupun siswanya. Sebagai pendidik, segala sikap dan perilaku yang dilakukannya tentu dapat dilihat dan dicontohkan oleh siswanya. Jika seorang guru tidak memiliki sikap kedisiplinan, maka tidak dapat disalahkan bila siswanya mengikuti perilaku guru.

Disiplin kerja yang baik mencerminkan besarnya tanggungjawab yang harus dipikul oleh guru terhadap tugas-tugas yang diberikan kepadanya, yang mendorong semangat kerja dalam mewujudkan tujuan organisasi. Untuk itu disiplin dalam bentuk pelaksanaan peraturan sangat diperlukan bagi kepala sekolah, guru, staf, dan peserta didik sebagai wujud nyata dari pengawasan dalam menciptakan tata tertib organisasi sekolah. Disiplin kerja yang baik juga mencerminkan kepribadian seorang guru yang memiliki rasa tanggungjawab yang tinggi, selain mempunyai intelektual yang tinggi dan wawasan yang luas dan berbagai kompetensi yang dimilikinya.

Berdasarkan data lapangan ditemukan bahwa guru di Sekolah Dasar Negeri Sawangan 02 Depok jarang sekali memulai pembelajaran dengan berdoa. Guru juga nampak memberikan tugas kepada siswanya tanpa menjelaskannya terlebih dahulu. Dilihat dari segi kepatuhan terhadap seragam sekolah yang diberlakukan, guru-guru di Sekolah Dasar Negeri Sawangan 02 Depok masih sering melakukan pelanggaran. Tidak hanya itu, saat jam pelajaran berlangsung, tidak sedikit guru yang asyik memperhatikan alat komunikasinya (handphone) dibandingkan memperhatikan kondisi kelasnya.

Sementara itu kedisiplinan belajar siswa di Sekolah Dasar Negeri Sawangan 02 Depok, berdasarkan hasil pengamatan diketahui bahwa siswa di Sekolah Dasar Negeri Sawangan 02 Depok sering keluar masuk kelas pada saat jam pelajaran berlangsung. Siswa di sekolah tersebut pun terlihat kurang bersemangat dalam belajar dan mengerjakan tugas-tugas yang diberikan oleh gurunya. Tidak hanya itu, siswa di Sekolah Dasar Negeri Sawangan 02 Depok sering tidak tertib saat jam pelajaran, seperti mengobrol dan juga bercanda di dalam kelas dengan temannya.

Berdasarkan identifikasi masalah maka rumusan masalah pada penelitian ini yakni 1) bagaimana penerapan disiplin kerja guru di Sekolah Dasar Negeri Sawangan 02 Depok? 2) 
bagaimana penerapan disiplin belajar siswa di Sekolah Dasar Negeri Sawangan 02 Depok? dan 3) bagaimana pengaruh disiplin kerja guru terhadap disiplin belajar siswa di Sekolah Dasar Negeri Sawangan 02 Depok?

\section{METODE PENELITIAN}

Metode penelitian yang digunakan yaitu pendekatan kuantitatif. Objek penelitian yakni pengaruh disiplin kerja guru dan disiplin belajar siswa. Penelitian dilakukan di Sekolah Dasar Negeri Sawangan 02 Depok.

Data dikumpulkan dengan cara penyebaran dan pengisian angket kepada 30 orang siswa sebagai responden. Uji validitas dan reliabilitas angket pada penelitian ini menggunakan program Statistical Package for the Social Sciences (SPSS) dengan tipe 21.00.

\section{HASIL DAN PEMBAHASAN}

\section{Data Hasil Uji Validitas dan Reliabilitas}

Uji validitas atau kesahihan item instrumen menghasilkan item valid dan tidak valid dengan kinerja $\mathrm{r}$ tabel 0.374 maka dikatakan valid.

\section{Uji Normalitas}

Setelah diperoleh angka persentase dari masing-masing angket, maka langkah selanjutnya yaitu mencari uji normalitas dengan menggunakan uji Kolmogorov-Smirnov Test dengan bantuan Software Program Statistical for Social Science (SPSS) tipe 21.00.

Tabel 1

Uji Normalitas Variabel Disiplin Kerja Guru Terhadap Disiplin Belajar Siswa One Sample Kolmogorov-Smirnov Test

\begin{tabular}{|ll|l|}
\hline & & \multicolumn{1}{c|}{$\begin{array}{c}\text { Unstandardized } \\
\text { Residual }\end{array}$} \\
\hline $\mathrm{N}$ & Mean & 30 \\
Normal Parameters & .0000000 \\
& Std, & 4.80776505 \\
Most Extreme & Deviation & \\
Differences & Absolute & .081 \\
& Positive & .074 \\
Kolmogorov-Smirnov Z & Negative & -.081 \\
Asymp Sig. (2 tailed) & & .443 \\
a. Test distribution is Normal & .989 \\
$b . \quad$ Calculated from data & \\
\hline
\end{tabular}

\section{Pembahasan}

Guru sebagai pendidik harus mampu menjadikan dirinya sebagai teladan. Teladan dalam hal ini bukan berarti guru harus menyerupai dirinya sebagai teladan. Teladan dalam hal ini bukan berarti guru harus menyerupai seseorang yang istimewa. Imron (Gusti, 2012) menyebut bahwa disiplin kerja guru adalah "suatu keadaan tertib dan teratur yang dimiliki oleh guru dalam bekerja di sekolah, tanpa ada pelanggaran-pelanggaran yang merugikan baik secara langsung maupun tidak langsung terhadap dirinya, teman sejawatnya dan terhadap sekolah secara keseluruhan".

Guru yang memegang teguh peraturan dan disiplin membuat guru mampu a) menyesuaikan diri dengan keadaan lingkungannya, b) patuh terhadap peraturan dan kepentingan serta kelancaran tugas sekolah, $\quad$ c) terbiasa hidup dengan baik positif dan bermanfaat bagi dirinya dan lingkungannya, d) mengontrol tingkah laku guru agar tugas-tugas di sekolah dapat berjalan secara maksimal, e) membentuk perilaku sedemikian rupa sehingga ia akan menyesuaikan dengan peran-peran yang ditetapkan kelompok budaya, tempat individu itu diidentifikasi (Hurlock, 1990).

Veithzal (Anggraini, 2014) mengemukakan bahwa terdapat empat perspektif daftar yang menyangkut disiplin kerja yaitu 1) disiplin retributive yaitu berusaha menghukum orang yang berbuat salah, 2) disiplin korektif yaitu berusaha membantu karyawan mengkoreksi perilakunya yang tidak tepat, 3) perspektif hakhak individu yaitu berusaha melindungi hak-hak dasar individu selama tindakan-tindakan disipliner, dan 4) perspektif utilitarian yaitu berfokus kepada penggunaan disiplin hanya pada 
saat konsekuensi-konsekuensi tindakan disiplin melebihi dampak-dampak negatifnya.

Helmi (1996) menyatakan disiplin kerja yang hanya diukur dengan kepatuhan dan ketaatan terhadap aturan dan jam kerja, kualitas disiplinnya masih taraf paling rendah. Peraturanperaturan yang dikemukakan di atas adalah disiplin yang kasat mata (dapat dilihat dengan mata). Seperti jam masuk, jam pulang, dan jam istirahat, cara-cara berpakaian, bertingkah laku dalam pekerjaan, yang boleh dilakukan dan apa yang tidak boleh dikerjakan.

Berdasarkan uji normalitas dengan Kolmogrov-Smirnov Test diperoleh nilai KSZ sebesar 0.443 dan Asym sig sebesar 0.989 lebih besar dari 0.05 maka dapat disimpulkan data berdistribusi normal. Untuk mengetahui data tentang disiplin kerja guru dengan menggunakan angket sebanyak 12 pertanyaan.

Berdasarkan hasil uji analisa rating scale diperoleh nilai angket sebesar 1150 dengan interval berkisar antara 1081-1440. Hal ini berarti bahwa penerapan disiplin kerja guru di Sekolah Dasar Negeri Sawangan 02 Depok dalam kategori "Sangat Baik". Adapun indikatornya dilihat dari kedisiplinan dalam waktu, terhadap tugas, terhadap suasana kerja dan sikap serta tingkah laku guru di sekolah.

Disiplin kerja guru Sekolah Dasar Negeri Sawangan 02 Depok yang diketahui dalam kategori "Sangat Baik" dipengaruhi oleh beberapa faktor. Hasibuan (2011:195-198) menjelaskan beberapa faktor yang mempengaruhi disiplin kerja guru diantaranya yaitu tujuan dan kemampuan, teladan pemimpin, balas jasa, keadilan, waskat, sanksi atau hukuman, ketegasan, dan hubungan

Sementara itu penerapan disiplin belajar siswa kelas IV di Sekolah Dasar Negeri Sawangan 02 Depok berdasarkan hasil uji analisa rating scalae diperoleh nilai angket sebesar 1494 dengan interval berkisar antara 1441-1920, sehingga dapat disimpulkan disiplin Belajar siswa kelas IV di Sekolah Dasar Negeri Sawangan 02 Depok kategori "Sangat Baik". Hal ini dapat dilihat dari kedisiplinan siswa dalam mengerjakan tugas-tugas belajar dan dalam menggunakan fasilitas belajar.

Adanya rasa kesadaran diri untuk melakanakan disiplin belajar pada siswa di Sekolah Dasar Negeri Sawangan 02 Depok didukung oleh beberapa faktor yang mempengaruhi disiplin belajar yaitu faktor internal, faktor eksternal dan faktor pendekatan belajar.

Adapun untuk mengetahui pengaruh disiplin kerja guru terhadap disiplin belajar siswa, penulis mengadakan penyebaran angket kepada 30 orang siswa sebagai responden dengan hasil jawaban sebagaimana dalam tabel frekuensi sebagai berikut

Tabel 2

Guru Mengakhiri Pelajaran Tepat Waktu

\begin{tabular}{|ll|l|l|l|l|}
\hline & Frequency & Percent & $\begin{array}{c}\text { Valid } \\
\text { Percent }\end{array}$ & $\begin{array}{c}\text { Cumulative } \\
\text { Percent }\end{array}$ \\
\hline \multirow{4}{*}{ Valid } & Kadang- & 3 & 10.0 & 10.0 & 10.0 \\
& kadang & & & & \\
& Sering & 14 & 46.7 & 46.7 & 56.7 \\
& Selalu & 13 & 43.3 & 43.3 & 100.0 \\
& Total & 30 & 100.0 & 100.0 & \\
\hline
\end{tabular}

Berdasarkan pada tabel 2 di atas untuk item nomor 1 menunjukkan bahwa 43.3\% (13 siswa) menjawab selalu, 46.7\% (14 siswa) menjawab sering, $10.0 \%$ (3 siswa) menjawab kadangkadang. Dalam hal ini guru mengakhiri pelajaran tepat waktu dengan besar pengaruhnya yaitu sering $46.7 \%$.

Tabel 3

Guru Meninggalkan Kelas Tepat Waktu

\begin{tabular}{|c|c|c|c|c|c|}
\hline & & Frequency & Percent & $\begin{array}{c}\text { Valid } \\
\text { Percent }\end{array}$ & $\begin{array}{c}\text { Cumulative } \\
\text { Percent }\end{array}$ \\
\hline Valid & $\begin{array}{l}\text { Kadang- } \\
\text { kadang }\end{array}$ & 6 & 20.0 & 20.0 & 20.0 \\
\hline
\end{tabular}


Iswan dan Indah Hadidah

PENGARUH DISIPLIN KERJA GURU TERHADAP DISIPLIN BELAJAR SISWA SEKOLAH DASAR REFLEKSI EDUKATIKA : Jurnal Ilmiah Kependidikan 10 (1) Desember 2019. Hlm. 121-127

\begin{tabular}{|l|l|l|l|l|}
\hline Sering & 11 & 36.7 & 36.7 & 56.7 \\
Selalu & 13 & 43.3 & 43.3 & 100.0 \\
Total & 30 & 100.0 & 100.0 & - \\
\hline
\end{tabular}

Sedangkan tabel 3 untuk item nomor 2 menunjukkan bahwa $43.3 \% \quad(13$ siswa $)$ menjawab selalu, $36.7 \%$ (11 siswa menjawab sering, $20.0 \%$ (6 siswa) menjawab kadangkadang. Dalam hal ini guru meninggalkan kelas sesuai waktu yang telah ditentukan dengan besar pengaruhnya yaitu selalu $43.3 \%$.

Berdasarkan data diketahui bahwa terdapat pengaruh yang cukup signifikan antara disiplin kerja guru terhadap disiplin belajar siswa kelas IV Sekolah Dasar Negeri Sawangan 02 Depok yang didukung angka korelasi sebesar 0.409 > $\mathrm{r}_{\text {tabel }} 0.374$ pada taraf signifikansi $5 \%$ dan juga hasil uji $\mathrm{F}$ yang menunjukkan $\mathrm{F}_{\text {hitung }}$ sebesar $5.617>\mathrm{F}_{\text {tabel }}$ sebesar 4.20. Karena nilai uji korelasi menunjukkan $r_{\text {hitung }}>$ dari $r_{\text {tabel }}$ dan hasil uji regresi sederhana menunjukkan bahwa $F_{\text {hitung }}>F_{\text {tabel }}$ maka dapat dinyatakan bahwa hipotesis terdapat pengaruh antara variabel disiplin kerja guru terhadap disiplin belajar siswa diterima. Sedangkan dilihat dari koefisien determinasi (R) sebesar $16.7 \%$ diketahui bahwa pengaruh antar variabel disiplin kerja guru terhadap disiplin belajar siswa ialah sebesar $16.7 \%$ yakni cukup berpengaruh.

Hasil penelitian ini senada dengan riset Jumirah (2016) yang menyatakan bahwa sebagian besar guru SMK Negeri 1 Barru sudah disiplin dalam melaksanakan tugas pembelajaran di sekolah dari aspek: 1) Merencanakan pembelajaran, 2) Melaksanakan pembelajaran, 3) mengevaluasi pembelajaran, dan melakukan tindak lanjut. Sementara itu penelitian Nugraheni (2016) menyimpulkan bahwa disipin kerja sangat berpengaruh positif dan signifikan terhadap kinerja guru di MI Al Islam Tempel dan MI Al Ihsan Medari, terlihat dari nilai thitung (Variabel X - Y $(7,450>2,262)$ ). Dari nilai R Square terlihat besaran sumbangan 0,686 atau $68,9 \%$ variabel kinerja guru dapat dijelaskan oleh variabel disiplin kerja, sedangkan sisanya $(100 \%-68,9 \%=31,1 \%)$ dipengaruhi oleh faktor lain yang tidak diteliti. Dan riset Husna (2017) yang menemukan that the work disciplinary variable has positive and significant impact to teachers' performance, that has been proven by the significant probability value 0,007 which is smaller than 0.05. Then, from the result of F test, it can be concluded that the regression model can be used to predict that the work disciplinary has positive and significant impact on teachers' performance that is equal to 0.007, which is much smaller than 0.05 .

Lebih lanjut penelitian ini memiliki persamaan dan perbedaan dengan riset Ariana (2013), Esa (2012) Johanes et al (2016), Nola (2014), Suroso (2007), Sutrisno (2013), dan Wahyudi (2012). Adapun persamaannya yaitu pada variabel disiplin kerja. Sementara itu perbedaannya yakni pada fokus penelitian sehingga temuannya pun berbeda.

Ariana (2013) yang menemukan The results has been obtained that are there are significant effects in simultaneously and partially between leadership, compensation, and discipline towards the employee's performance in the Hotel Cendana Ubud Resort \& SPA. Sementara itu riset Esa (2012) yang menunjukkan bahwa : 1) Motivasi terbukti berpengaruh terhadap kinerja karyawan. 2) Kemampuan terbukti berpengaruh terhadap kinerja karyawan. 3) Displin terbukti berpengaruh terhadap kinerja karyawan.

Penelitian Gusti (2012) dengan masil penelitian yang menunjukkan bahwa: (1) Tidak terdapat pengaruh yang signifikan antara disiplin kerja terhadap kinerja guru di SMKN 1 Purworejo pasca sertfikasi, dengan tingkat pengaruh variable kedisiplinan sebesar 0,106; (2) Tidak terdapat pengaruh yang signifikan antara Motivasi kerja terhadap kinerja guru di SMKN 1 Purworejo pasca sertfikasi, dengan tingkat pengaruh variabel Motivasi kerja sebesar 0,074; (3) Tidak terdapat pengaruh yang signifikan antara persepsi guru tentang kepemimpinam kepala sekolah terhadap kinerja guru di SMKN 1 Purworejo pasca sertifikasi, dengan tingkat pengaruh persepsi guru tentang kepemimpinam kepala sekolah sebesar 0,027 ; (4) Terdapat hubungan yang signifikan antara variabel disiplin kerja, motivasi kerja, dan persepsi guru tentang kepemimpinam kepala sekolah secara simultan terhadap kinerja guru di SMKN 1 Purworejo pasca sertfikasi, dengan tingkat pengaruh sebesar 0,123 .

Adanya pengaruh pengaruh antara disiplin kerja guru terhadap disiplin belajar siswa menunjukkan bahwa guru memegang peranan penting dalam menanamkan nilai-nilai dalam diri siswa sebagai usaha membentuk watak dan kepribadian siswa. Guru sebagai pembimbing 
harus berupaya untuk membimbing dan mengarahkan perilaku siswa ke arah yang positif, dan menunjang pembelajaran.

Membimbing dalam hal ini dapat dikatakan sebagai kegiatan menuntun anak didik dalam perkembangannya dengan jalan memberikan lingkungan dan arah yang sesuai dengan tujuan pendidikan, termasuk dalam hal ini, yang penting ikut memecahkan persoalan-persoalan atau kesulitan yang dihadapi anak didik. Karena itu, guru digambarkan sebagai pembawa pemikiran dan dakwah, yang berusaha ke arah tersebut dan mencari metode yang efektif serta cara yang terbaik untuk mencapai tujuan. Guru juga harus disifati dengan segenap sifat dan kesabaran, kelembutan, keikhlasan, serta dedikasinya dalam pekerjaan. Seorang guru hendaknya dapat meneladani sifat dan sikap para Nabi dan Rasul, khususnya Nabi Muhammad SAW karena pada diri beliau terdapat suri teladan yang baik.

Guru sebagai pengawas senantiasa mengawasi seluruh perilaku siswa, terutama pada jam-jam efektif sekolah, sehingga jika terjadi pelanggaran terhadap disiplin, dapat segera diatasi. Sebagai pengendali, guru harus mampu mengendalikan seluruh perilaku peserta didik di sekolah. Dalam hal ini guru harus mampu secara efektif menggunakan alat pendidikan secara tepat sasaran, baik dalam memberikan hadiah maupun hukuman terhadap siswa. Sebagai pendidik/fasilitator belajar, guru harus mampu menerapkan kepemimpinannya dalam rangka mendorong, memotivasi dan mempengaruhi peserta didik agar dapat belajar lebih baik, lebih bersemangat dan berdisiplin belajar yang tinggi.

Perlu diingat oleh setiap guru, bahwa pengaruh antara murid dan guru hendaknya berdasarkan pengertian dan kasih sayang, sehingga murid itu hormat dan sayang kepada gurunya, dan bukan karena takut ataupun benci. Pengaruh yang baik itu dapat membantu kecintaan anak terhadap pelajaran yang diberikan kepadanya.

\section{SIMPULAN}

Disiplin kerja yang baik mencerminkan besarnya tanggungjawab yang harus dipikul oleh seseorang terhadap tugas-tugas yang diberikan kepadanya, yang mendorong semangat kerja dalam mewujudkan tujuan organisasi. Untuk itu disiplin dalam bentuk pelaksanaan peraturan sangat diperlukan bagi guru dan peserta didik sebagai wujud nyata dari pengawasan dalam menciptakan tata tertib organisasi sekolah.
Disiplin kerja yang baik juga mencerminkan kepribadian seorang guru yang memiliki rasa tanggungjawab yang tinggi, selain mempunyai intelektual yang tinggi dan wawasan yang luas dan berbagai kompetensi yang dimilikinya. Guru yang selalu dapat melaksanakan tata tertib dengan baik dan dapat memberikan contoh yang baik pula kepada siswanya, sehingga siswa dapat menilai antara guru yang disiplin dengan guru yang tidak disiplin.

\section{DAFTAR PUSTAKA}

Ariana, I Wayan Tresna dan I Gede Riana. 2013. Pengaruh Kepemimpinan, Kompensasi dan Disiplin Kerja Terhadap Kinerja Karyawan Pada Hotel Cendana Resort \& Spa Ubud, Gianyar. E-Jurnal Manajemen Universitas Udayana, 2 (1).

Arikunto, Suharsimi. 2010. Prosedur Penelitian Suatu Pendekatan Praktek. Jakarta: PT. Rineka Cipta.

Anggraini, Lela. 2013. Pengaruh Intensitas Pembinaan Mental Islami Terhadap Kedisiplinan Kerja dan Dalam Menjalankan Ibadah Shalat Lima Waktu di Korem 073 Salatiga Tahun 2013. Skripsi. Salatiga: Sekolah Tinggi Islam Negeri Salatiga.

Esa, Kresna Wahyu., dan Prawitasari, Dian. 2012. Pengaruh Motivasi, Kemampuan dan Disiplin Terhadap Kinerja Karyawan pada PT. Samudra Indonesia di Semarang. Jurnal Jurusan Manajemen Fakultas Ekonomi dan Bisnis Universitas Dian Nuswantoro (-): 1-11.

Gusti, Messa Media. 2012. Pengaruh Kedisiplinan, Motivasi Kerja, dan Persepsi Guru Tentang Kepemimpinan Kepala Sekolah Terhadap Kinerja Guru SMKN 1 Purworejo Pasca Sertifikasi. Jurnal Penelitian Program Studi Teknik Elektro Fakultas Teknik Universitas Negeri Yogyakarta (-): 1-12

Helmi. Avian Fadilla. 1996. Disiplin Kerja. Jurnal Buletin Psikologi 2 (4): 32-41. 
Hurlock. Elizabeth B. 1978. Perkembangan Anak. Jakarta: Erlangga.

Husna, Nikmatul. 2017. Pengaruh Disiplin Kerja Terhadap Kinerja Guru Pada SMAN 1 Canduang Kabupaten Agam. Jurnal EKOBISTEK, 6 (2): 286-298.

Johanes, E.A., et al. 2016. Pengaruh Motivasi Dan Disiplin Kerja Terhadap Kinerja Pegawai Pada Dinas Pertanian Kabupaten Supiori. Jurnal Agri-Sosio Ekonomi, 12 (3a): 27-24.

Jumriah, J., Akib, Haedar, Akib., dan Darwis, Muhammad Darwis. 2016. Disiplin Kerja Guru Dalam Melaksanakan Tugas Pembelajaran Di Sekolah Menengah Kejuruan Negeri 1 Barru. Jurnal Office, 2 (1): 155-162.

Nola. Ananda Vitra. 2014. Hubungan Kepemimpinan Kepala Sekolah dengan Disiplin Kerja Guru di Sekolah Menengah Kejuruan Negeri (SMKN) Kota Solok. Jurnal Administrasi Pendidikan, 2 (1): 45-55.
Nugraheni, Aninditya Sri dan Rahmayanti, Ratna. 2016. Pengaruh Disiplin Kerja Terhadap Kinerja Guru di MI Al Islam Tempel dan MI Al Ihsan Medari. Jurnal Pendidikan Madrasah, 1 (2): 277-293.

Sudijono. Anas. 2011. Pengantar Statistik Pendidikan. Jakarta: Rajawali Pers.

Suroso dan Khafid, Muhammad. 2007. Pengaruh Disiplin Belajar dan Lingkungan Keluarga Terhadap Hasil Belajar Ekonomi. Jurnal Pendidikan Ekonomi Fakultas Ekonomi Universitas Negeri Semarang 2 (2):185-204.

Sutrisno, Sugeng. 2013. Pengaruh Disiplin Kerja Dan Motivasi Kerja Terhadap Kinerja Pegawai Negeri Sipil (Study Dikantor Dinas Sosial Provinsi Jawa Tengah). Jurnal Ilmiah Dinamika Ekonomi Dan Bisnis, 1 (1): 1-11.

Wahyudi, Adi., Thomas, Partono., dan Setiyani, Rediana. 2012. Pengaruh Disiplin Kerja, Motivasi Kerja, Dan Supervisi Kepala Sekolah Terhadap Kinerja Guru. Economic Education Analysis Journal 1 (2):

$1-8$. 